\title{
Visual Impairment and Mental Health Outcomes: Lack of Research Output from India
}

\author{
*Prem Kumar SG \\ Mission for Vision, Mumbai, India
}

Submission: June 19, 2017; Published: June 26, 2017

*Corresponding author: SG Prem Kumar, Mission for Vision, Maker Chamber VI, 220 Jamnalal Bajaj Marg, Nariman Point, Mumbai, India, Tel No: (+91 22) 2282 4967/94; E-mail: pkumar@missionforvision.org.in

\section{Opinion}

"Depression: let's talk" is the theme of this year's World Health Day. This is a timely call, as mental health is generally still under-recognised. Blindness continues to be one of the major public health problems in developing countries. As per census India - 2011, about $2.2 \%$ of the total population are disabled and of which $18.8 \%$ are visually disabled - the second highest form of disability. According to the publically-funded National Program for Control of Blindness (NPCB), cataract and refractive errors account for over $82 \%$ of visual impairment (VI) in India [1].

The research both from India and other parts of the world has revealed that VI increases with increasing age [2,3]. It is also estimated that people aged 50 years and older comprise $65 \%$ and $82 \%$ of the total visually impaired and blind, respectively [2]. VI leads to reduced quality of life (QoL) [4,5], poorer general health [6], lower social status and increased mortality $[7,8]$. Most studies in low-vision samples in developed and developing or transitional countries such as India have found healthy associations between best-corrected vision impairment and improvements in overall quality of life of the patients [912]. However, the impact of such intervention in gauging the emotional well-being of patients has been weak [10].

The WHO estimates that people with VI are three times more likely to suffer from depression and anxiety disorders [13]. There is a dearth of information on mental health issues among the visually impaired in India. However, evidence from elsewhere indicate higher levels of depressive disorders and severe anxiety symptoms amongst older as well as younger patients with VI, much higher than those found among the general population in the community $[14,15]$. Among visually impaired children, high prevalence of psychiatric morbidity has been reported previously $[16,17]$. There was only one study among children with VI in India that reported a prevalence of psychiatric comorbidity of $8.7 \%$ [18].
The major trends of public health research in India since 2001 show an increase in the public health research output from India over the past few years. But, the quality of research in public health is not yet satisfactory enough and distributions of research areas are too inconsistent with the disease burden trends [19]. Public mental health is major health system component, which continues to be overlooked. The consequences of mental health issues for patients with VIs are far-reaching. Depression, in general, is associated with greater functional disability, morbidity, and mortality among middleaged and older adults. Furthermore, adults with comorbid vision loss and depression are less likely to seek, be referred to, or use vision rehabilitation services; and those who do seek care tend to receive less service compared to those who are not depressed. Given these consequences, access to the services of the mental health system and the integration of mental health services into the vision rehabilitation system clearly represent high priorities in the organization of services for people with vision impairments. There is thus an urgent need to identify the force multiplier for mental health in India.

A dedicated Mental Health Policy and the recent mental health care bill 2014 are definitely right steps in this direction. Yet, there remain extensive gaps in services and widespread unmet mental health needs among people who are visually impaired. In an era where 'inclusive development' is being emphasized as the right path towards sustainable development, focused initiatives for the welfare of disabled persons are essential. There is an urgent need to develop and conduct further scientific research to understand the dynamics and interplay of mental health outcomes among visually-impaired children, adolescents and adults in India

\section{Acknowledgment}

The views expressed in this opinion piece are those of the author's and do not necessarily reflect the views of the institution employing the author. 


\section{References}

1. National Control for Control of Blindness. Director General of Health Services, Ministry of Health and Family Welfare, Government of India.

2. Pascolini D, Mariotti SP (2011) Global estimates of visual impairment. Br J Ophthalmol 96(5): 614 -618.

3. Dandona L, Dandona R, Srinivas M (2001) Blindens in the Indian state of Andhra Pradesh. Invest Ophthalmol 42(5): 908-916.

4. Polack S, Eusebio C, Fletcher A, Foster A, Kuper H (2010) Visual impairment from cataract and health related quality of life: results from a case-control study in the Philippines. Ophthalmic Epidemiol 17(3): 152-159.

5. Finger RP, Kupitz DG, Holz FG, Bala subramaniam B, Ramani RV (2011) The impact of the severity of vision loss on vision-related quality of life in India: an evaluation of the IND-VFQ-33. Investigative Ophthalmology and Visual Science 52: 6081-6088.

6. Taylor HR, Katala S, Munoz B, Turner V (1991) Increase in mortality associated with blindness in rural Africa. Bull World Health Organ 69(3): 335-338

7. Sengupta M, Agree EM (2002) Gender and Disability Among Older Adults in North and South India: Differences Associated with Coresidence and Marriage. Journal of Cross-Cultural Gerontology 17: 313-336.

8. Foley D, Chowdhury J (2007) Social Exclusion and the Politics of Disability: Care as a Social Good and the Expenditure of Social Capital in Chuadanga, Bangladesh. Social Policy \& Administration 41(4): 372 385.

9. Nirmalan PK, Tielsch JM, Katz J (2005) Relationship between vision impairment and eye disease to vision-specific quality of life and function in rural India: the Aravind Comprehensive Eye Survey 46(7): 2308-2312
10. Finger RP, Fenwick E, Marella M (2011) The impact of vision impairment on vision-specific quality of life in Germany 52(6): 36133619.

11. Fletcher A, Vijaykumar V, Selvaraj S, Thulasiraj RD, Ellwein LB (1998) The Madurai Intraocular Lens Study. III: Visual functioning and quality of life outcomes. Am J Ophthalmol 125(1): 26-35.

12. Rovner BW, Casten RJ(2002) Tasman WS. Effect of depression on vision function in age-related macular degeneration. Arch Ophthalmol 120(8): 1041-1044.

13. World Health Organisation. The eye care info-graphic. WHO, Geneva, Switzerland

14. Horowitz A, Reinhardt JP, Kennedy G(2005) Major and sub-threshold depression among older adults seeking vision rehabilitation services. American Journal of Geriatric Psychiatry 13(3): 180-187.

15. Brennan M, Cardinali G (2000) Religiousness and spirituality in adaptation to vision impairment among middle-age and older adults. In C. Stuen (Ed), Vision rehabilitation: Assessment, intervention and outcomes, Swets \& Zeitlinger, Netherlands, pp. 645-649.

16. Jan JE, Freeman RD, Scott EP (2000) Visual impairment in children and adolescents. Hersov L, Child and Adolescent Psychiatry, Modern Approaches ( $3^{\text {rd }}$ edn), Blackwell Science, USA, pp. 729.

17. Koenes SG, Karshmer JF (2000) Depression: A comparison study between blind and sighted adolescents. Issues Ment Health Nurs 21(3): 269-279.

18. Bakhla AK, Sinha VK, Verma V, Sarkhel S (2011) Prevalence of psychiatric morbidity in visually impaired children. Indian Pediatr 48(3): 225-227.

19. Dandona L, Raban MZ, Guggilla RK, Bhatnagar A, Dandona R (2009) Trends of public health research output from India during 2001-2008. BMC Med 7: 59.

\section{Your next submission with Juniper Publishers will reach you the below assets}

- Quality Editorial service

- Swift Peer Review

- Reprints availability

- E-prints Service

- Manuscript Podcast for convenient understanding

- Global attainment for your research

- Manuscript accessibility in different formats

( Pdf, E-pub, Full Text, Audio)

- Unceasing customer service

Track the below URL for one-step submission https://juniperpublishers.com/online-submission.php 